\title{
A question of religion or orientation: Hall \& Preddy $v$ Bull and the possible effect of the Equality Act 2010
}

by James Hand and Pat Feast

$\mathrm{T}$ he county court decision in Hall \& Preddy $v$ Bull [2011] EW Misc 2 (CC) provides a further example of judicial consideration of the interplay of religion and sexual orientation discrimination, following such cases as McFarlane v Relate Avon [2010] EWCA Civ 880 and Ladele $\checkmark$ London Borough of Islington [2009] EWCA Civ 1357 (which dealt respectively with religious objections to providing sex therapy and civil partnership ceremonies to homosexuals). The judgments in the latter cases together with such examples as Chaplin ${ }_{v}$ Royal Devon \& Exeter Hospital NHS Foundation Trust [2010] ET 1702886/2009 and Eweida v British Airways [2010] EWCA Civ 80 (which both held that prohibitions regarding wearing crucifixes were not discriminatory), and the furore over the threat to Catholic adoption agencies during the passage of the Equality Act 2006 (with many subsequently closing), caused leading clerics to criticise an imbalance in discrimination law and opine that the religious rights of the Christian community are being treated with disrespect (see, eg Daily Telegraph Letters, March 28, 2010; Montgomery, J W, "Religious 'irrationality' and civil liberties”, (2010) 82 Amicus Curiae, 12).

\section{THE CASE}

Hall \& Preddy v Bull is a rare discrimination case involving the provision of services and shows that an Englishman and Englishwoman's home is not necessarily their castle. Mr and Mrs Bull had for many years run a private hotel near St Ives in Cornwall. They are devout Christians and had sought to run their hotel on Christian principles, with texts on some of the walls and the statement on their online booking form that "Here at Chymorvah we have few rules, but please note, that out of a deep regard for marriage we prefer to let double accommodation to heterosexual married couples only - thank you".

Mr Hall and Mr Preddy are civil partners, who lived in Bristol. They wanted to go on a short break, with their pet dog, to Cornwall in September 2008 and Mr Preddy made a telephone booking for two nights in a double room at the Chymorvah Private Hotel, having seen that it was a dogfriendly establishment. As the booking was by telephone, they did not see the restriction on who could book double rooms and Mrs Bull, who took the booking, did not, contrary to her usual practice because she was feeling unwell, let them know of the restriction. The first Mssrs Hall and Preddy knew of it was when they turned up at the hotel. Their protestation that they were civil partners did not help them, and the refusal to let them have a double room, while not done in a demeaning manner according to Mr Preddy, took place in the public reception area in the presence of other guests.

One wonders as to the content of the discussion at this point. Has society's quest to "pigeon hole" its members led to a situation where anyone who is not overtly heterosexual must be subjected to questioning as to their sexual orientation? Would Mrs Bull have questioned two females in the same way - perhaps, because of her religious conviction, she would have felt compelled to do so. But what of a situation where two guests who are in a same sex relationship arrived but having read the notice on the webpage page, decided to ask for a double room with twin beds so as to save any embarrassment - would these have been questioned? The evidence as to this during the hearing was unclear, but the judge, although initially uncertain, was satisfied with the amended defence that such rooms would be let if available (although noting that if an unmarried couple - heterosexual or homosexual wished to embark on a "sexually fulfilling weekend", the hotel policy "allows them so to do albeit in the confines of a smaller bed" (at para [34])).

Having gone on to find a different hotel, and had their deposit refunded, Messrs Hall and Preddy sought a declaration and damages under the then extant Equality Act (Sexual Orientation) Regulations 2007 (SO Regs 2007). 


\section{THE LAW (AT THE TIME)}

Regulation 4 of the SO Regulations 2007 held that it was unlawful, when providing goods, facilities or services to the public, to discriminate against a person by, among other things, refusing to provide those services or by providing those services on different terms (see now s 29 Equality Act 2010). This was not at issue in this case which was argued solely on whether the Bulls' action constituted direct or indirect discrimination (and whether such a construction was compatible with the European Convention on Human Rights).

Regulation 3(1) of the SO Regulations 2007 held that a person ("A") discriminates against another("B") if, on grounds of the sexual orientation of $B$ or any other person except A, A treats B less favourably than he treats or would treat others (in cases where there is no material difference in the relevant circumstances). The argument for the defence in the present case was that the discrimination was not on grounds of sexual orientation but had "everything to do with 'sex." Indeed, in 1996 the hotel had appeared in newspaper stories because the Bulls refused double rooms to unmarried heterosexual couples; and the twin-bedded rooms were available to people regardless of their marital status or sexual orientation. However, Judge Rutherford disagreed with that analysis and considered that the Bulls were discriminating on the basis of marital status. Pointing to Regulation 3(4) of the SO Regulations 2007, which specify that when making the comparison the fact that one person is a civil partner while the other is married is not to be treated as a material difference, he held that the only conclusion which he could draw was that the refusal to allow them to occupy the double room was because of their sexual orientation. To put it another way, not that he used such language, "but for" the claimants' sexual orientation if they were heterosexual and thus married (any differences between marriage and civil partnership not being material for the purposes of the Regulationss) - they would not have been less favourably treated.

In case he was in error, Judge Rutherford then went on to consider indirect discrimination. The defendants had accepted that the restriction on the occupation of double rooms constituted a "provision, criterion or practice" which was applied to the claimants and equally to persons not of their sexual orientation (reg 3(3)(a)). They contested, however, that the restriction placed persons of the claimants' sexual orientation at a disadvantage compared to some or all others (where there is no material difference in the relevant circumstances) and further that, if it did, that they could not reasonably justify the restriction by reference to matters other than B's sexual orientation (reg 3(3)(b) \& (d)). Judge Rutherford, however, held that it was clear that homosexuals as a group were disadvantaged by the practice and that to allow the justification would create a class of persons whose views rendered them exempt from the discrimination legislation and that such a defence would be too wide.

\section{THE EUROPEAN CONVENTION}

Article 9(1) of the European Convention on Human Rights establishes a general right to freedom of "thought, conscience and religion" which cannot be restricted by the state; however Article 9(2) establishes that the right to 'manifest' one's religion or belief in 'worship, teaching, practice and observance' may be restricted. Article 9 can be invoked alongside other Convention rights and thus, for example, Article 10 can be considered if there are restrictions placed on religious expression and Article 8 may be relevant if any restriction interferes with the individual's private life. If the issue is in connection to the manifestation of religion, the court is likely to focus on Article 9 as it was in the case before us. Judge Rurtherford queried whether the running of the hotel along Christian principles could be described as manifesting one's religion but came to the conclusion that it could. However, the Christian religion could be regarded as a forward thinking and tolerant faith and does it therefore require that marital status can only be achieved via a heterosexual marriage contract? (This is something which is due to come under much scrutiny in the next few years). Does the manifestation of the religion require this observance? In Eweida v British Airways plc [2010] EWCA Civ 80, for example, it was successfully argued that the wearing of a crucifix was not indirect discrimination because, inter alia, the wearing of a crucifix was not an essential element of the Christian faith.

Irrespective of these questions as to Article 9(1), Judge Rutherford held that such manifestation was in any case subject to Article 9(2) and the SO Regulations 2007 were both a necessary and proportionate intervention by the state to protect the rights of others. By contrast, he did not believe that the Bull's Article 8 rights to respect for their private and family life were infringed as the regulations did not affect the private part of the hotel where they lived (their privacy in the guest areas inevitably being affected by their choice to run part of their home as an hotel) but if he were wrong then, again, the right could properly be limited as the regulations could be deemed both necessary to protect the convention rights of the claimants and to do so proportionately.

\section{TEMPORA MUTANTUR...?}

As Judge Rutherford points out, social attitudes have changed in recent decades and it was not so very long ago that the genuinely held beliefs of the defendants would have been accepted as normal by society. Some establishments may have turned a blind eye to unmarried couples sharing a room, but it would not then have been a widespread practice. Such was also the era of signs outside boarding houses stating "no blacks, no dogs, no Irish." Since those days we have had a raft of equality legislation alongside changes in social attitudes.

However, even before the advent of equality legislation, innkeepers were under a duty not to refuse guests if 
deemed to be "travellers" rather than lodgers or boarders. This common law duty had been in existence for around 500 years and the relevant definition of an inn or hotel can now be found in section 1(1) of the Hotel Proprietors Act 1956: an establishment held out by the proprietor as offering food, drink and, if so required, sleeping accommodation, without special contract, to any traveller presenting himself who appears able and willing to pay a reasonable sum for the services and facilities provided and who is in a fit state to be received. Thus when, in Constantine v Imperial London Hotels Ltd [1944] 1 KB 693, $\mathrm{Mr}$ Constantine, an afro-Caribbean British subject and man of high character, was turned away from the Imperial hotel despite having booked a room and paid the deposit, the hotel company was liable, albeit only in nominal damages. However, if there had been a special contract such as is the case with boarding houses, lodgings and guesthouses - then there would have been no duty. The discrimination legislation expressly included boarding houses within its remit (eg s 20(2)(b) Race Relations Act 1976, reg 4(2)(b) SO Regs 2007) but allowed a limited exception for small communal accommodation (eg s 22 RRA 1976, reg 6(2) SO Regs 2007).

\section{THE EQUALITY ACT 2010}

Hall \& Preddy v Bull and all the earlier cases took place under the original discrimination legislation, as will the appeal of the case due later this year. The new, unifying, Equality Act 2010 replicates much of the former provisions, with the definitions of direct and indirect discrimination appearing in sections 13(1) and 19, the statement regarding the lack of materiality of the difference between marriage and civil partnership in section 23(3) and the prohibition of discrimination in providing services in section 29 (although the list of activities is no longer included) and the communal accommodation exception in Schedule 5. Within these provisions there has been very little change to the law.

However, if a similar scenario to Hall \& Preddy $v$ Bull occurred today the claimants could potentially take advantage of a significant change. Under section 45(1) of the Equality Act 2006, a person ("A") discriminated against another ("B") if on grounds of the religion or belief of B or of any other person except A (whether or not it is also A's religion or belief) A treated B less favourably than he treated or would have treated others, whereas the unified direct discrimination provision in the Equality Act 2010 (defined in s 13(1)) refers to less favourable treatment because of a protected characteristic. There is in the new Act no limitation with regard to the protected characteristic of religion preventing the religion in question from being that of the discriminator. Accordingly, rather than it being a question of the interplay of sexual orientation and religion, and the possible imbalance therein decried by leading clerics among others, the claim could now appear to take place solely based on the protected characteristic of religion as the less favourable treatment would be because of the views of the defendants.

\section{James Hand}

Associate Senior Lecturer, School of Law, University of Portsmouth

Pat Feast

Senior Lecturer, School of Law, University of Portsmouth 